\title{
E-Banking Challenges in Pakistan: An Empirical Study
}

\section{Zahoor Hussain1, Dayal Das², Zulfiqar Ali Bhutto1, Muhammad Hammad-u-Salam³, Fauzia Talpur ${ }^{1}$, Glub Rai ${ }^{4}$}

${ }^{1}$ IICT, University of Sindh, Jamshoro, Pakistan

${ }^{2}$ Sindh Madressatual Islam University, Karachi, Pakistan

${ }^{3}$ University of Management Science and Information Technology (UMIST), Kotli, Pakistan

${ }^{4}$ Computer Science, Education \& Literacy Department, Government of Sindh, Karachi, Pakistan

Email: zahoorshah@scholars.usindh.edu.pk, Das.dayal16@gmail.com, Zulfiqar.bhutto@usindh.edu.pk,

hammad.salam@yahoo.com, f9_talpur@hotmail.com

How to cite this paper: Hussain, Z., Das, D., Bhutto, Z.A., Hammad-u-Salam, M., Talpur, F. and Rai, G. (2017) E-Banking Challenges in Pakistan: An Empirical Study. Journal of Computer and Communications, $\mathbf{5}$, $1-6$.

https://doi.org/10.4236/jcc.2017.52001

Received: January 3, 2017

Accepted: January 22, 2017

Published: January 25, 2017

Copyright $\odot 2017$ by authors and Scientific Research Publishing Inc. This work is licensed under the Creative Commons Attribution International License (CC BY 4.0).

http://creativecommons.org/licenses/by/4.0/

(c) (i) Open Access

\begin{abstract}
Electronic banking has provision networks that replaces and replicated various activities currently executing by the bank. Hence e-banking now plays a vital role to carry out the individual as well as corporate financial activities execution. Even e-banking activities based on the internet or virtual private networks own by the bank, therefore communication channel, distribution channel and transactions channel must be secure. The research article explores the current trends in the e-banking uprising that has set a goal in the Pakistani banking sector to provide any easy interface to their customers which avail the e-banking services without any physical presence in the bank vicinity. This empirical study was carried out in Pakistan which indicating the current issues encounter by the e-banking application in various banking industries. The analysis in this paper further reveals that approachability of internet in banking sector makes customer reluctant to access their bank accounts electronically. The usage of e-banking significantly affects the customer trust due to unavailability of cyber security.
\end{abstract}

\section{Keywords}

E-Banking, Technologies, E-Banking Transactions, Challenges

\section{Introduction}

E-Banking is not something new to Pakistan. The first ever ATM machine was installed in 1987 in Pakistan. Till late 1990s, the installation and growth rate of ATM machine were remained low and slow. However, the real growth in ATM machine and ATM cards issuance were seen in 1999 after establishment of na- 
tional switches links and accelerated the issuance of ATM cards with the SBP (State Bank Pakistan) circular 2002. The issuances of cards for accountholders were mandatory to every bank and must connect to two ATM links [1]. SBP played a vital role in the e-banking evolution by providing supporting atmosphere. With determinations of State Bank Pakistan as a supervisor, it covered way for banks to issue cards to accountholders and provide entrance to bank financial records over ATM machine by integrating the bank with single link or multiple links. State Bank of Pakistan later directed in 2006 the two networks must have interconnectivity, which made it conceivable for any account holder of any bank to take the cash out from any bank across the country via ATM card [2]. The SBP has introducing new rules to further improvement of the quality of services rendering by the various banks in Pakistan and make it ensure the account holder services have not be compromised. With the economic growth in Pakistan the financial activities increased [3] which led to benefits for ATM networks. The vast number of financial activities by the ATM network also led to provide innovative solutions to accountholder such as easy, fast, cost effective and secure ATM links. The various banks in Pakistan offer different services to their cardholders for example, fund transfer to same and different banks, payment of utility bills by cards and inter banking transaction facilities [4]. This growth in e-banking will led to introducing the branchless banking concept in banking sector. The banking sector also introduced various cards for their customers such as Debit card, Credit cards, and Visa cards. Figure 1 shows the total installed ATM machine, online branches, plastic cards, e-banking transactions and other kinds of transactions in Pakistan [5]. Due to the integration of internet services with banking sector many challenges have been raised [6]. This research paper indicates some of them by conducting the survey. The article consists with five sections. Section one comprises the introduction of e-banking. Section two covers the e-technologies and Section three presents the e-transactions. Section four indicated the challenges in e-banking and finally Section five drew the conclusion.

\section{E-Banking Technologies}

The banking business has been expressively prone by growth of information technology. The growing submissions of computerized linkages to banking sec-

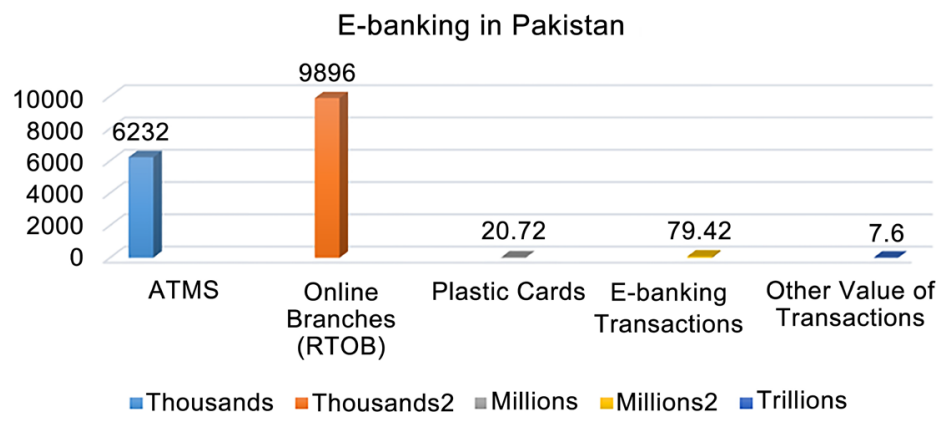

Figure 1. E-banking Transaction figure and facts. 
tor compact the charge of operation and amplified the swiftness of deals extensively. The nature of financial mediators made banks advance their invention tools by concentrating on dissemination of products. In other words, the advancement of banking information technology has been essentially motivated by variations in scattering networks such as from tele-banking, phone-banking, $\mathrm{pc}$ banking over-the counter (OTC) and automated-teller-machine (ATM), and most recently internet banking (IB) [7]. The various commercial banking sectors go through with rapid transformation due to information and communication services, as the international and national economy grow and spread towards market and industrial completeness. A main vigor behind these progresses is an information technology, which breach the industrial, geographical and regulatory barriers and increases the production of innovative services, products, systems oriented business, developing more information, market opportunities and management processes [8].

\section{E-Banking Transactions}

In 2011, according to surveys of the Federal Reserve Board's Division of Consumer and Community Affairs. The FRBD conducted its first Survey of Consumer Use of Mobile for financial transactions. Since that time, the acceptance of mobile financial facilities has persistent to rise, beside with the variety of facilities offered. Furthermore, the board continued to conduct the surveys annually to monitor the consumers' attitudes towards the mobile financial activities [9]. According to survey of the 2014 conducted by GfK, an online consumer research company, on behalf of the US FRBD (Federal Reserve Board's Division) and its shows the statistics of mobile banking and mobile payments. Figure 2 shows the statistics of mobile banking and mobile payments [9].

According to SBP 2014 and 2015 reports, Pakistan has witnessed a huge flow in retail banking financial transactions over past decades with ATM cards accounting for $64 \%$ of entire E-banking financial transactions. The real time online banking (RTOB) percentage is $24 \%$ by the year of $2014 \& 2015$, carried out by

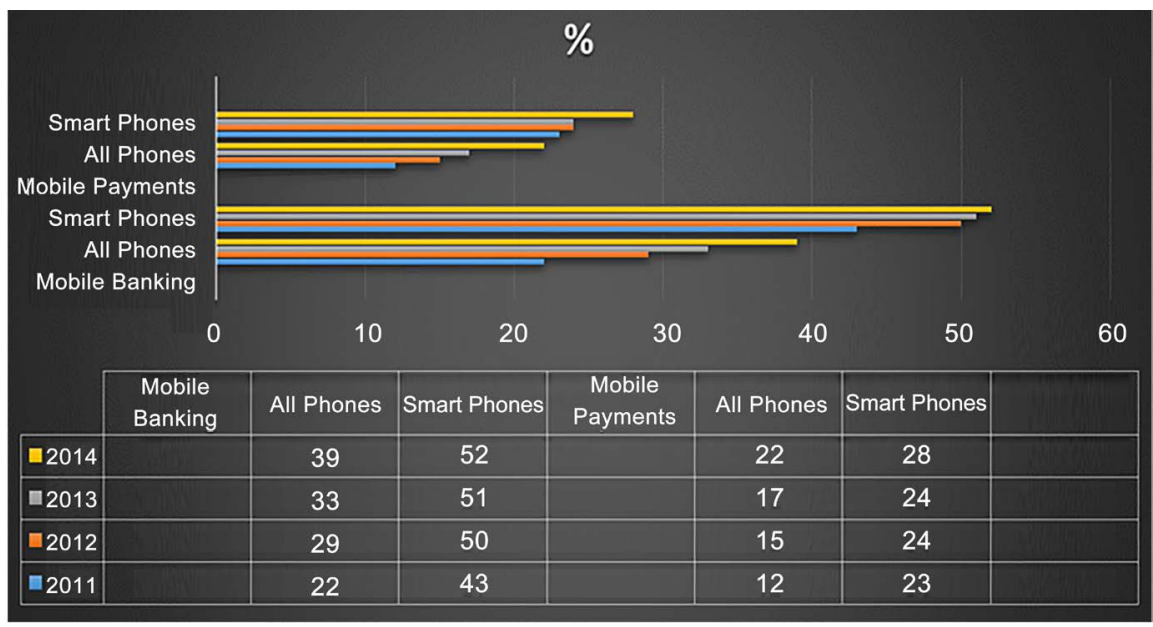

Figure 2. Mobile phones banking and mobile phones payments. 
the core banking system. Since the last five years, the E-banking financial transactions witnessed a considerable growth. The volume of e-banking increased by 100\% from 235 million to Rs. 247 million. The volume of e-banking further increased by 2010 to 2015 from 22.1 Trillion to Rs.35.8 Trillion [10]. Figure 3 depicts the e-banking composition services in Pakistan.

\section{Challenges in E-Banking}

The first ever ATM machine was installed in 1987 in Pakistan. However, this article indicated the problems from (2011 to 2016) encounter by ATM machines. According to research survey by different sources of various banks in Pakistan revealed the day to day problems faced by their non-technical staff. Figure 4 shows the various problems faced by the non-technical staff of banking sector.

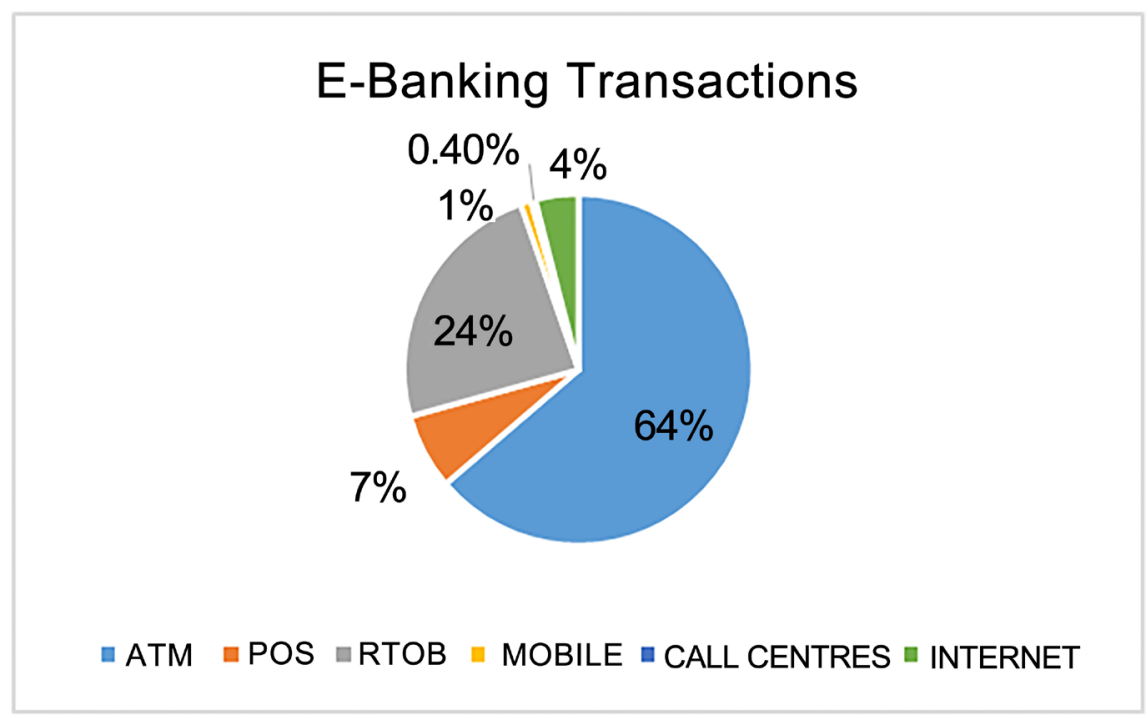

Figure 3. E-banking service composition in Pakistan.

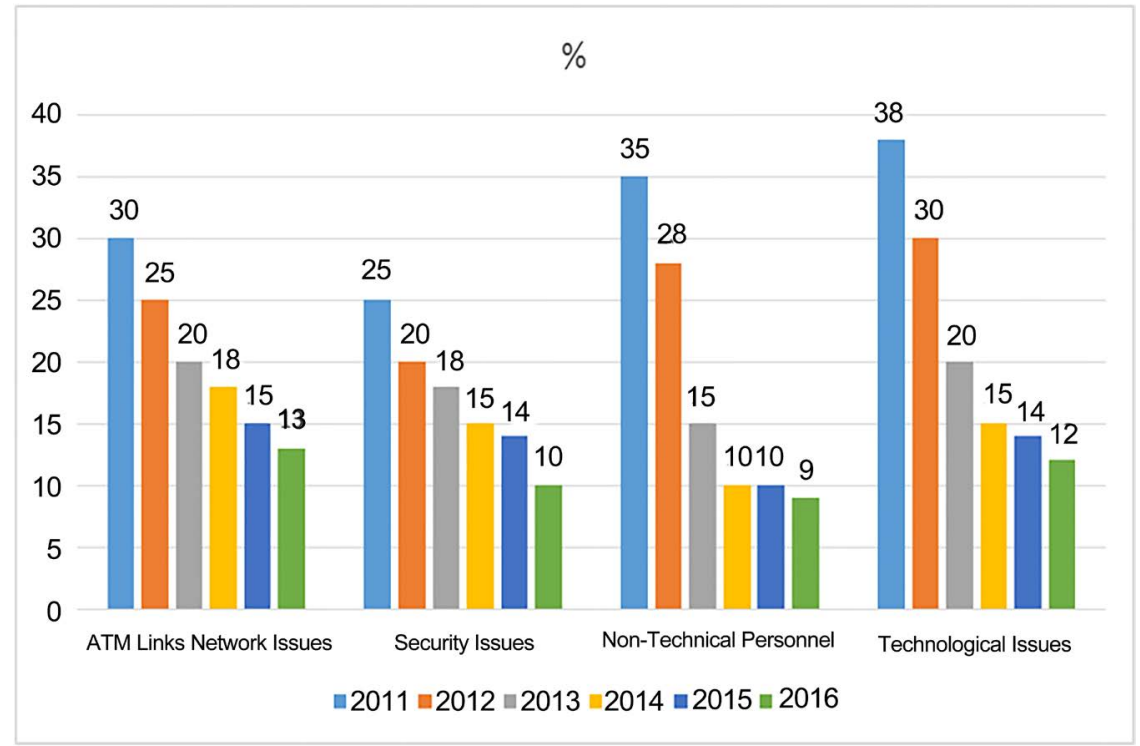

Figure 4. Technological problems in e-banking. 


\subsection{Technological Issues}

The transfer of financial transactions to the Internet is a certain expansion in the information technology era. From the last decade, several banks have launched e-banking over the Internet and specified the necessities of identical marginal advantages beside marginal overheads, appraising the market productivity and development along with specific dimensions and sectors. In addition, the commercial banking sector face major encounters on both the supply side and demand side due technological changes. Furthermore, competition related particular with, quality of service and disparity, security of transaction, cost proficien$\mathrm{cy}$, and demographic change [11]. Figure 4 shows the technological problems encounter by various bank by different years.

\subsection{ATM Links Network Issues}

The progress of financial transactions by technology has been driven by variations in scattering networks as demonstrated by ATM (automated teller machine), Mobile Phone-banking, Pc-banking, Telebanking and most recently internet banking [12] [13]. Due to improper links capacity and connectivity of ATM links the customers faced various issues for example false reporting about cash, more cash deduction during transaction, late delivery of cash, links down and ATM is out of services. Figure 4 shows the different years variation due to improper ATM links connectivity and links capacity.

\subsection{Security Issues}

Figure 4 shows the security threats encounter by different bank by different frequencies during year 2011 to 2016. The main challenge for banking sector is extensively usage of information technology applications related to e-banking. Which causes e-security threats, cyber-attacks on customers profile, account hijacking, frauds in terms of data messages, theft customers privacy, get secrecy of financial transactions.

\subsection{Non-Technical Personnel}

Another major threat faced by the banking industry was their non-technical staff and improper training sessions. Mostly the bank sector preferred to appoint those people who belong to banking education or commerce and business education for execution of banking activities. However due to least knowledge of information technology the security and privacy of customers have remained compromised and the cyber-criminals easily targets the non-technical personnel systems.

\section{Conclusion}

Most of the financial bank transactions in Pakistan were conducted at the bank branches in person and manually. The arrival of ICT (information \& communication technology) and accessibility of quick and trustworthy internet connec- 
tivity from the last decade have enabled the expansion of e-banking networks in the country. The faster internet availability provides more facilities to bank customers such as easier cash withdrawal, faster money transfer, web application for customers and reducing the branches of banks. Beside the advantages, the banking sector also faced the cyber threats due to internet connectivity such as transactions security, privacy of customers' accounts-threats and banking system security. This research article indicates the essential challenges faced by the banking industry in Pakistan.

\section{References}

[1] Risafi, N.N., Hunter, B.D., McKenzie, K., Wiggins, J., Stangle, B. and Forte, V. (2014) Mastercard International Incorporated, System and Method for Using a Prepaid Card. US Patent 8675840.

[2] Roof, B.J., Yeh, A.S., Mizes, H.A., Du, H. and Yang, M., Xerox Corporation (2016) Gnition Business Model and Method for Identifying Perpetrators of Atm Fraud. US Patent 20160125404.

[3] Siddiqi, A. (2013) The Emerging Social Contract: State-Citizen Interaction after the Floods of 2010 and 2011 in Southern Sindh, Pakistan. IDS Bulletin, 44, 94-102. https://doi.org/10.1111/1759-5436.12036

[4] Khan, M.A. and Mahmood, B. (2016) Analytical Study to Find the Effects of Control and Punishment on White Collar Crimes in Punjab, Pakistan. Pakistan Journal of Criminology, 8, 107.

[5] Habib, A. (2015) A Comparison of Financial Performance of Banking Industry in Pakistan. Journal of Poverty, Investment and Development, 13, 1-10.

[6] Naseem, S.Z., Saleem, Y., Zagham, S., Umar, A.M., Shafiq, M. and Saleem, M. (2013) Analysis of Different Atm Interfaces in Pakistan to Minimize Cognitive Burden for Interaction. Pakistan Journal of Science, 65.

[7] Shaikh, A.A. and Karjaluoto, H. (2015) Mobile Banking Adoption: A Literature Review. Telematics and Informatics, 32, 129-142. https://doi.org/10.1016/j.tele.2014.05.003

[8] Liao, Z. and Cheung, M.T. (2002) Internet-Based e-Banking and Consumer Attitudes: An Empirical Study. Information \& Management, 39, 283-295. https://doi.org/10.1016/S0378-7206(01)00097-0

[9] Board of Governor of the Federal Reserve System (2015) Consumers and Mobile Financial Services 2015. www.federalreserve.gov/pubs/orderform.pdf

[10] Statistical-Look-at-Payment-System-and-Retail-Banking-of-Pakistan-for-2014-15. https://propakistani.pk/2015

[11] Liao, Z. and Cheung, M.T. (2003) Challenges to Internet e-Banking. Communications of the ACM, 46, 248-250. https://doi.org/10.1145/953460.953507

[12] Arulambalam, A., Chen, X. and Ansari, N. (1996) Allocating Fair Rates for Available Bit Rate Service in ATM Networks. IEEE Communications Magazine, 34, 92 100. https://doi.org/10.1109/35.544198

[13] Hasan, A.S., Baten, M.A., Kamil, A.A. and Parveen, S. (2010) Adoption of e-Banking in Bangladesh: An Exploratory Study. African Journal of Business Management, 4, 2718 . 
Submit or recommend next manuscript to SCIRP and we will provide best service for you:

Accepting pre-submission inquiries through Email, Facebook, LinkedIn, Twitter, etc. A wide selection of journals (inclusive of 9 subjects, more than 200 journals)

Providing 24-hour high-quality service

User-friendly online submission system

Fair and swift peer-review system

Efficient typesetting and proofreading procedure

Display of the result of downloads and visits, as well as the number of cited articles Maximum dissemination of your research work

Submit your manuscript at: http://papersubmission.scirp.org/

Or contact jec@scirp.org 